\title{
Corpos de Afeto: festejos do Vale do Jequitinhonha e o processo criativo "Vale da Esperança"
}

\author{
Mariana Floriano \\ Universidade Estadual de Campinas - UNICAMP, Campinas/SP, Brasil \\ floriano_mari@hotmail.com \\ Graziela Estela Fonseca Rodrigues \\ Universidade Estadual de Campinas - UNICAMP, Campinas/SP, Brasil \\ graziela@iar.unicamp.br
}

\section{Resumo}

Este artigo trafega pelas terras mineiras do Vale do Jequitinhonha e revela o Boi-Janeiro de Maria Coqui, com seu rico manancial social e afetivo, como parte de um processo de desenvolvimento artístico no Método Bailarino-Pesquisador-Intérprete (BPI) e da criação cênica do espetáculo "Vale da Esperança". Apresenta um estudo corporal do festejo do Boi-Janeiro em intrínseca relação com a manifestação religiosa dos reiseiros da família Coqui. Aponta para o que emana no corpo do intérprete quando esta coabita com pessoas em que a resistência cultural é latente.

Palavras-chave

Bailarino-Pesquisador-Intérprete. Artes da Cena. Dança do Brasil. Boi-Janeiro.

\section{Abstract}

This article travels through the lands of Jequitinhonha Valley revealing the Maria Coqui's Boi-Janeiro, with its opulent social and affective contents, as part of an artistic creative process in the Dancer-Researcher-Performer Method (BPI) and of the scenic creation "Vale da Esperança". It also presents a corporal study of Boi-Janeiro's festivals in an intrinsic relation with the religious manifestation of the reiseiros from Coqui's family. It indicates what comes from the performer's body when he cohabits with people whom cultural resistance is latent.

Keywords

Dancer-Researcher-Performer. Performing Arts. Dance of Brazil. Boi-Janeiro. 
O Vale do Jequitinhonha ${ }^{1}$, famoso por ser uma das regiões mais pobres do Brasil, possui os mais elevados índices de pobreza, desnutrição, mortalidade, analfabetismo, desemprego e déficit de infraestrutura socioeconômica, que ocasiona êxodo rural para os grandes centros urbanos e esvaziamento demográfico persistente. Somado a isso, ainda existe a carência de investimentos públicos e privados na região (IBGE, 1997). A região tem sido reconhecida, muitas vezes, como o Vale da Miséria, mas ganha nos tempos atuais um "contradiscurso" que o legitima como o Vale da Cultura, devido à sua riqueza cultural (SERVILHA, 2012).

"O Vale do Jequitinhonha, embora estigmatizado ao longo do tempo pelo estereótipo miserável da carência, em função da existência de sérios problemas de ordem social e econômica, agravados por fatores de ordem ambiental, também apresenta uma rica cultura, que se manifesta de várias formas entre o seu povo. Assim, poderíamos caracterizar a região em função dos seus extremos, mas extremos que interagem entre si, num processo dialético configurando a realidade vivenciada pelos moradores do Vale do Jequitinhonha". (NASCIMENTO, 2009, p. 9).

Em 1987, a segunda autora, juntamente com dois ajudantes de pesquisa e um chofer dirigindo uma Kombi, adentrou o Vale do Jequitinhonha ${ }^{2}$. A dificuldade em realizar o tra-

10 Vale do Jequitinhonha integra-se a bacia hidrográfica do rio Jequitinhonha que abrange parte do nordeste de Minas Gerais e pequeno setor do sul da Bahia. A bacia totaliza uma área de aproximadamente $70 \mathrm{mil} \mathrm{km} \mathrm{km}^{2}$, sendo 66.319 situado em MG e 3.996 na BA. O Vale do Jequitinhonha compreende a região mineira dessa bacia, possuindo 52 munícipios, subdivididos em três zonas (Alto, Médio e Baixo Jequitinhonha) e em cinco microrregiões (Almenara, Araçuaí, Capelinha, Diamantina e Pedra Azul). (IBGE, 1997 e 1990).

2 Essa viagem era parte do projeto "Trilhas e Veredas da Dança Brasileira" desenvolvido pela segunda autora entre os anos de 87 e 88, com financiamento da Bolsa Vitae de Artes. Foram percorridos 10 municípios e uma infinidade de danças, rituais jeto programado, envolvendo atolamentos e dificuldades de prosseguir viagem, fazia com que, muitas vezes, o chofer apavorado anunciasse desistir de continuar a viagem ou a veIha Kombi, que heroicamente resistiu, ficava na eminência de parar ao longo do percurso. Aquele homem, que conduzia o veículo, não conseguia entender como aquelas pessoas passavam por tudo aquilo com o propósito de buscar Bois-Janeiros, folias, contradanças e uma instigante dança da chuva que nunca foi encontrada.

Os lugares eram realmente precários. Era de duvidar que em meio a tanto lixo e aspereza pudesse sair um folguedo de boi. E saia. Era uma vibração, uma força, uma beleza, um encantamento difícil de ser traduzido em palavras. Os pés mastigando o chão de pedras, o figurino em papel crepom desbotado e em chita rasgada são imagens emblemáticas para se entender o simbolismo do corpo nessa região.

O material originário dessa expedição foi disponibilizado para os alunos do curso de Graduação em Dança da Universidade Estadual de Campinas (UNICAMP) ao longo de todos esses anos. A primeira autora desse artigo, quando ainda aluna da graduação, se interessou por este material e realizou duas idas ao Vale do Jequitinhonha, primeiramente para a cidade de Almenara em $2006^{3}$ e, posteriormente, em 2009 para a cidade de Pedra Azul ${ }^{4}$.

e manifestações foram encontradas e registradas em vídeo, áudio e fotografia.

3 Pesquisa de Campo junto às lavadeiras de beira de rio como parte da disciplina Dança do Brasil IV do curso de Graduação em Dança da UNICAMP.

4 Pesquisa de Campo na festividade Boi de Janeiro como parte do Projeto de Iniciação Científica "A questão do afeto no Método BPI através de pesquisa de campo no Vale do Jequitinhonha", orientado pela segunda autora, financiado pela FAPESP. 
Já na pós-graduação ${ }^{5}$, em 2016, junto à uma auxiliar de pesquisa, a autora realizou uma ida para a cidade de Rubim em busca de reaver o Boi de Maria Coqui, motivada pelas imagens e dados das pesquisas realizadas anteriormente.

Andando pelas ruas de Rubim, em 1988, a segunda autora deparou-se com um terreiro onde meninos brincavam efusivamente com um boizinho confeccionado de cabo de vassoura coberto por estopa e de uma cabeça feita de lata de óleo. Uma alegria contagiante fez com que, esta cena captada em vídeo na épo$\mathrm{ca}$, encantasse a todos que dessa imagem pudessem usufruir. Naquele momento desconhecia-se que aquele lugar pertencia a uma dona de Boi muito especial: Maria Coqui. Naquela manhã ensolarada, adentrando o seu terreiro pode-se ver pela janela aberta, dentro da casa, que ali havia outro Boi, também de brinquedo, acomodado na sala, ao lado de uma Bonecona. Maria Coqui apareceu e disse que somente à noite, sairia com o seu Boi-Janeiro em cortejo pelas ruas da cidade.

Antes de prosseguir é preciso notificar a presença dos folguedos de boi por todo o Brasil, integrados às mais variadas devoções e associados a ritos mágico-religiosos. Bumba-meu-boi, Boi Calemba, Boi-Bumbá, Boi de Reis, Boi Pintadinho, Cavalo Marinho, Boi Surubim, Boi de Janeiro, Boi de Mamão, Boizinho são algumas das variações que se difundiram, manifestando-se nos ciclos natalino, junino e carnavalesco (BORBA, 1966; CASCUDO, 2012).

"Não esqueçamos também a importância simbólica do Boi em toda a bacia do Mediterrâneo e especificamente na Península Ibérica. "Encarnação das forças genésicas", o Boi era ao mesmo tempo um símbolo de transformação, e da angustia que toda transformação desperta. Mas para que o tema tivesse podido se conservar na memória coletiva, ao passar de um continente a outro e com todas as modificações de gênero de vida que isto implica, era preciso que correspondesse a uma realidade e a necessidades profundas". (MEYER, 1991, p. 62).

O Boi-Janeiro ou Boi de Janeiro é uma manifestação popular encontrada na Bahia e em Minas Gerais. A denominação em comum nestas regiões não configura o acontecimento festivo como o mesmo, pois este contém particularidades intrínsecas a cada localidade em que se faz presente. O Boi-janeiro caracteriza-se "por um conjunto de elementos que, de forma inter-relacionada, dão particularidades à sua estrutura, aos seus aspectos estéticos, históricos e socioculturais" (BRITO e outros, 2016, p. 294), consolidando, para cada núcleo comunitário, uma manifestação que mantém a fé dirigida aos santos católicos do ciclo natalino.

Neste artigo é através do Boi-Janeiro de Maria Coqui que as pesquisas de campo realizadas na cidade de Rubim, distanciadas por quase trinta anos encontram-se e é através desse recorte que ambas as pesquisadoras descortinam os sentidos aí incrustados que se conectam a uma dramaturgia de necessidades profundas.

5 Projeto de Doutorado "Expandindo o Método BPI para crianças de 5 a 10 anos considerando o campo simbólico dos festejos de boi no Brasil", orientado pela segunda autora no PPGADC da UNICAMP, financiado pela CAPES. 
Figura 1: Pesquisadora (à direita) grava a fala de um dono de Boi. De Pedra Azul, 1988. Foto: Ricardo Oliveira.

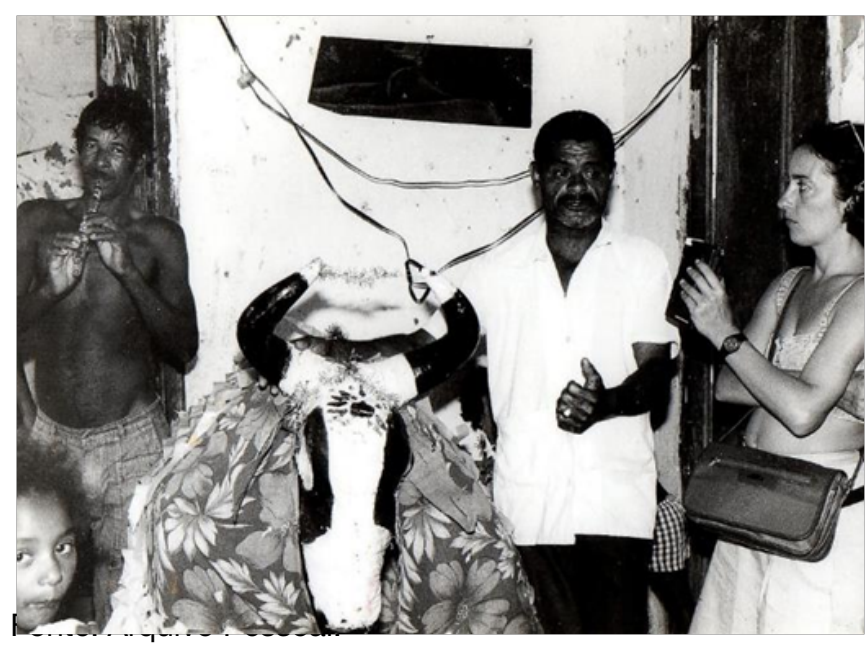

Fonte: Arquivo Pessoal.

Figura 2: Reiseiros no terreiro de Maria Coqui. Rubim, 1988. Foto: Ricardo Oliveira.

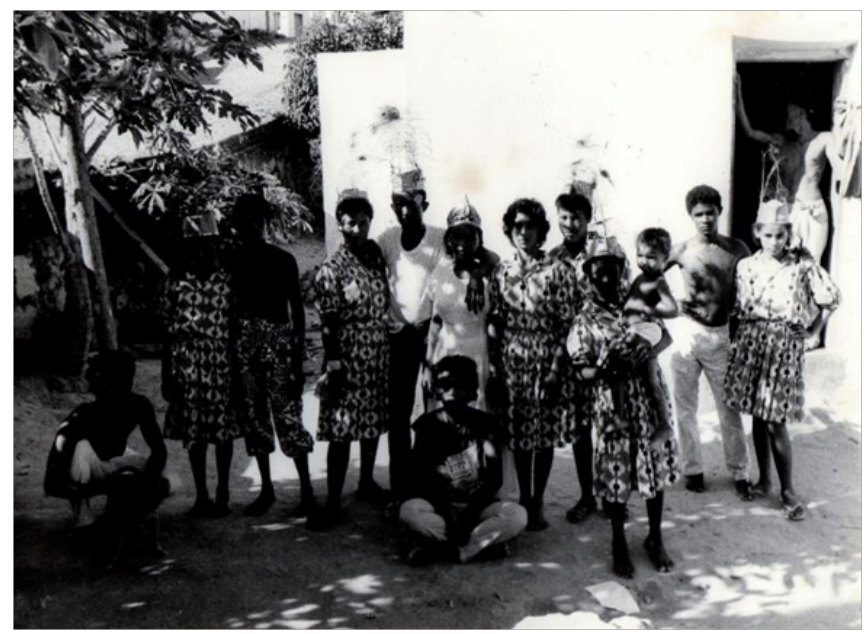

Fonte: Arquivo Pessoal.

\section{— Levanta Boi Janeiro pra nóis vadia $!$}

"É hoje! É hoje!" anunciava um dos foliões dentro da casa de Maria Coqui. Enquanto isso, na rua, a comunidade da cidade de Rubim aguardava sentada no meio fio das calçadas. Os meninos escoravam-se nas janelas e na porta da casa dos Coquis com os olhares

6 O termo vadiar era explicado pelos integrantes do grupo como sendo "brincar na rua" No dicionário Aurélio vadiar possui 6 diferentes sentidos, sendo um deles "brincar, divertir-se" (FERREIRA, 1999, p. 2041). atentos a qualquer movimento do Boi e da Bonecona. O "entra e sai de foliões", dos parentes e dos meninos, antes de serem expulsos da sala por Maria Coqui, dinamizava todo o entorno da casa. Cada minuto passado, agitava ainda mais o ambiente. Afinal, "é hoje! É hoje! É dia de Boi-Janeiro, pessoal!"

O festejo realizado pelo grupo familiar de Maria Coqui, no ano de 2016, caracterizava-se pela brincadeira de um boi carcaça ${ }^{7}$ pelas ruas da cidade. Junto a ele, encontravam-se uma bonecona escorregadia chamada Maria Manteiga, três mascarados arruaceiros - a Lobinha, o Bate-na-cara e o Velho - que corriam atrás dos meninos e dançavam pelas ruas da cidade. Além destes, havia também um grupo de mulheres batuqueiras, representando as Pastorinhas e a Rainha, o vaqueiro companheiro do bichano e os tocadores - um alegre grupo de ritmistas.

O Boi-Janeiro era feito de uma estrutura de madeira amarada de forma envergada e revestida pelo "couro", que consistia em um tecido simples pintado com tinta preta. A sua cabeça e chifres eram partes da ossada de um boi, finalizados com tecido, e os olhos e os outros detalhes da cabeça tinham os acabamentos feitos com tinta. Seu rabo era também retirado do animal, no qual ficava somente a ponta de couro empalhada e parafusada na parte de trás da carcaça.

A dinâmica da brincadeira era composta por um cortejo pelas ruas da cidade e por uma roda, no qual os personagens eram "apresen-

7 A utilização do termo carcaça refere-se à estrutura/armação, confeccionada pelos brincantes, que representará o Boi na festividade. É comum a utilização desse termo entre os brincantes de boi.

80 termo couro nas brincadeiras de boi apresentava-se como o revestimento da carcaça, equiparando-se à pele do bovino no âmbito festivo. 
tados". A roda é uma dinâmica presente em diversas manifestações populares, e nessa ocasião, elas eram realizadas na frente da casa de pessoas que pediam a apresentação em troca de uma prenda. Nas rodas os personagens se ajeitavam em um grande círculo, rodeado pela comunidade que era parte integrante do festejo. $\mathrm{O}$ vaqueiro organizava o grupo e iniciava a "apresentação" dos personagens com cantoria, sempre acompanhado pelas pastorinhas, que davam voz ao coro.

Nas apresentações, cada personagem tinha seu momento e uma trilha sonora que acompanhava o ritmo de seus movimentos. O mais esperado era o Boi-Janeiro que trazia a sambada ao som do batuque. A sambada consistia em um movimento pendular e lateral da carcaça, envolvendo giros, em que o rabo do boi disparava no ar e, também, pontuações da carcaça para frente, em que os chifres investiam contra uma pessoa do público ou dentre os foliões. Em um determinado momento, todos os personagens se juntavam ao Boi Janeiro ao que eles chamavam de baile, marcando o encerramento da roda.

Com o fim da roda de apresentação dos personagens, o grupo retornava para o cortejo. A caminhada pelas ruas de Rubim movimentava a comunidade junto ao Boi de Maria Coqui. Todos os personagens iam junto, vadiando pela rua. A brincadeira de boi no cortejo era caracterizada pela dinâmica do enrabar ${ }^{9}$, que consistia no movimento de correr atrás das crianças e jovens. A provocação da criançada era o combustível para a enrabada. Os três mascarados, o Boi Janeiro e a Nega percorriam as ladeiras de pedras da cidade divertin- do e amedrontando ao mesmo tempo.

As diversas manifestações do boi no Brasil, tem seu ciclo festivo marcado pelo batismo e pela morte do novilho. Esses fenômenos são associados à tradição cristã. (IPHAN/MA, 2011). Carvalho (2009) diz que o batismo introduz o boi no mundo, configurando o seu nascimento e fazendo com que o boi não saia pagão pelas ruas. No Boi-Janeiro de Maria Coqui, embora não tenha sido observado o batismo, a brincadeira detém um ciclo que se iniciou com a armação da carcaça do boi e da bonecona e se encerrou com a morte do boi, no dia 7 de Janeiro.

Para o autor (CARVALHO, 2009), a morte do boi demarca a despedida do boi no ano. Em Rubim, a despedida dos personagens trouxe tristeza para as crianças que choravam ao lado da carcaça. Porém, no Boi-Janeiro de Maria Coqui foi possível perceber que a morte do boi carregava em sua realização um campo emocional que ia além da tristeza pelo fim da festividade. A morte do bichano foi cantada em versos que, dividindo o boi, partilhava-o simbolicamente com a comunidade. Era um último respiro de vida que exaltava alegria e esperança.

$O$ vaqueiro recolheu o boi da rua, levando-o para dentro da casa. A festividade encerrou-se com a dispersão da criançada. 
Figura 3: Meninos na sala de Maria Coqui a espera do Boi. Rubim, 2016. Foto: Mariana Floriano.

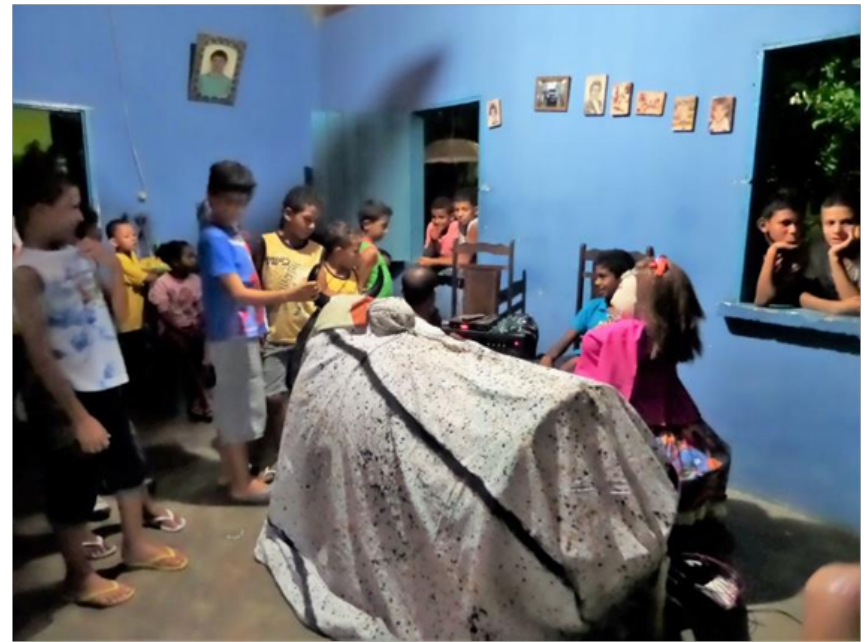

Fonte: Arquivo Pessoal.

Figura 4: Boneca Maria Manteiga e boi janeiro. Rubim, 2016. Foto: Mariana Floriano.

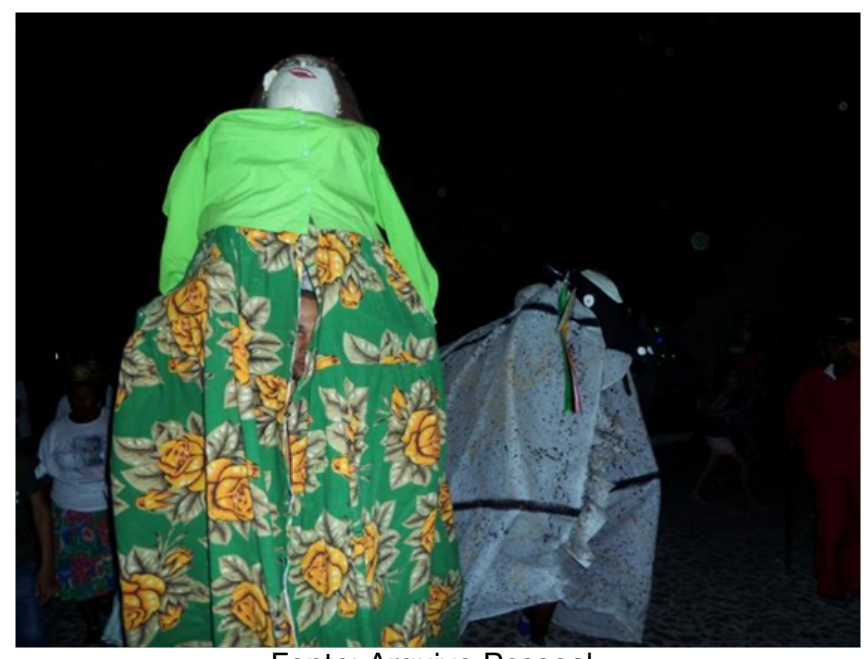

Fonte: Arquivo Pessoal.

Figura 5: Bate-na-cara durante a roda. Rubim, 2016. Foto: Mariana Floriano.

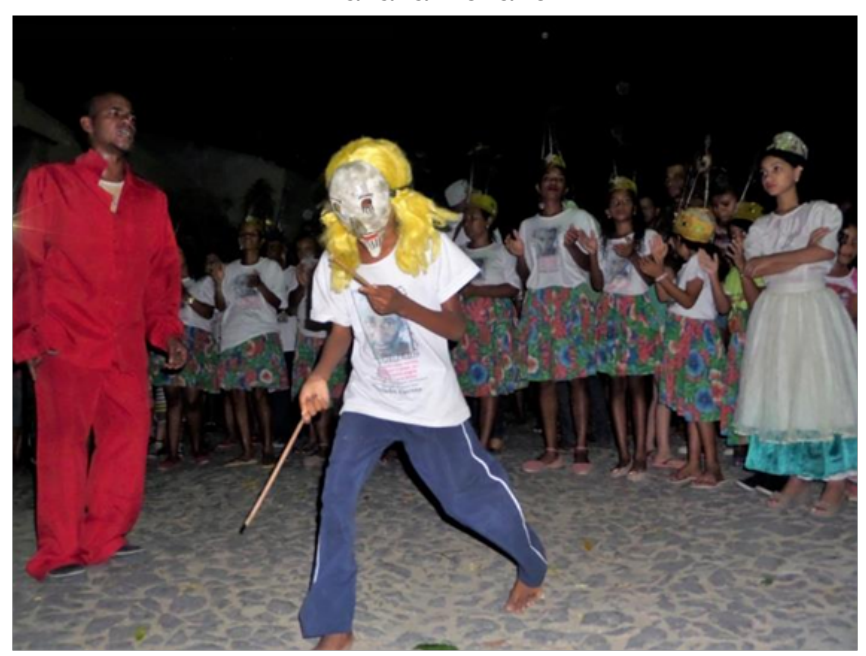

Fonte: Arquivo Pessoal.
Figura 6: Velho durante a roda. Rubim, 2016. Foto: Mariana Floriano.

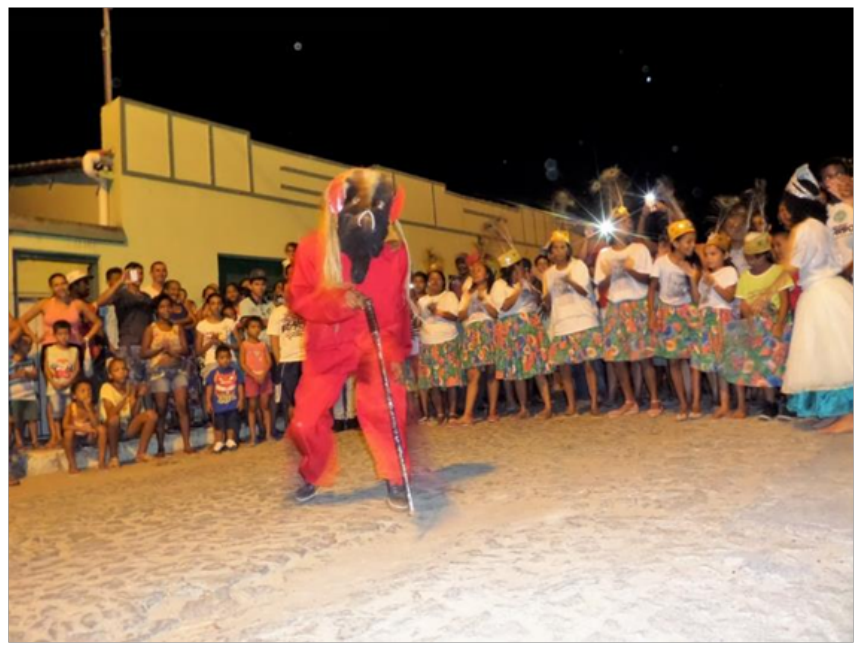

Fonte: Arquivo Pessoal.

Figura 7: Lobinha de Ouro. Rubim, 2016. Foto: Mariana Floriano

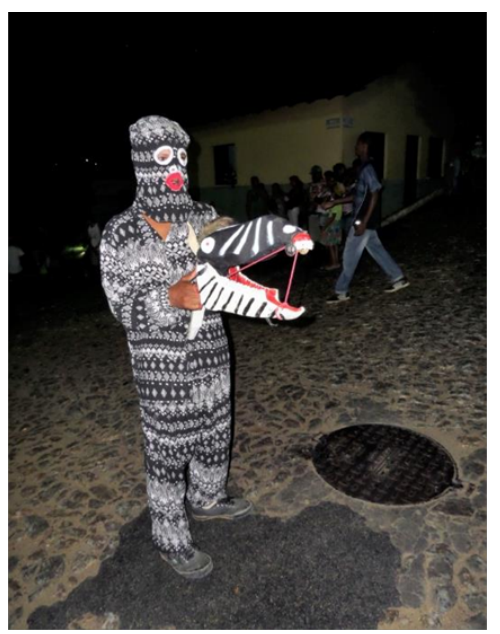

Fonte: Arquivo Pessoal.

Figura 8: Lobinha enrabando menino. Rubim, 2016. Foto: Mariana Floriano.

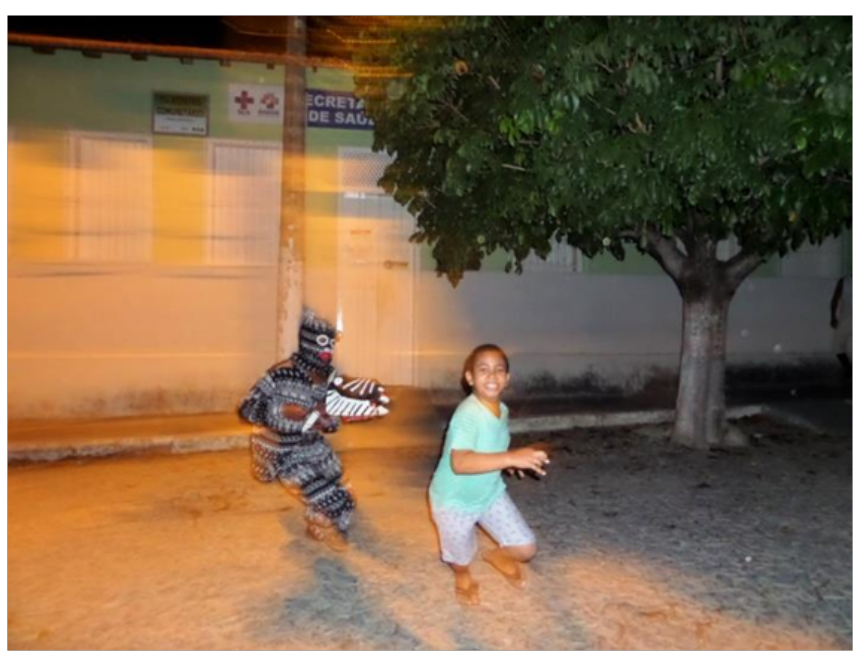

Fonte: Arquivo Pessoal. 
Figura 9: Baile com as pastorinhas e Maria Manteiga. Rubim, 2016. Foto: Mariana Floriano.

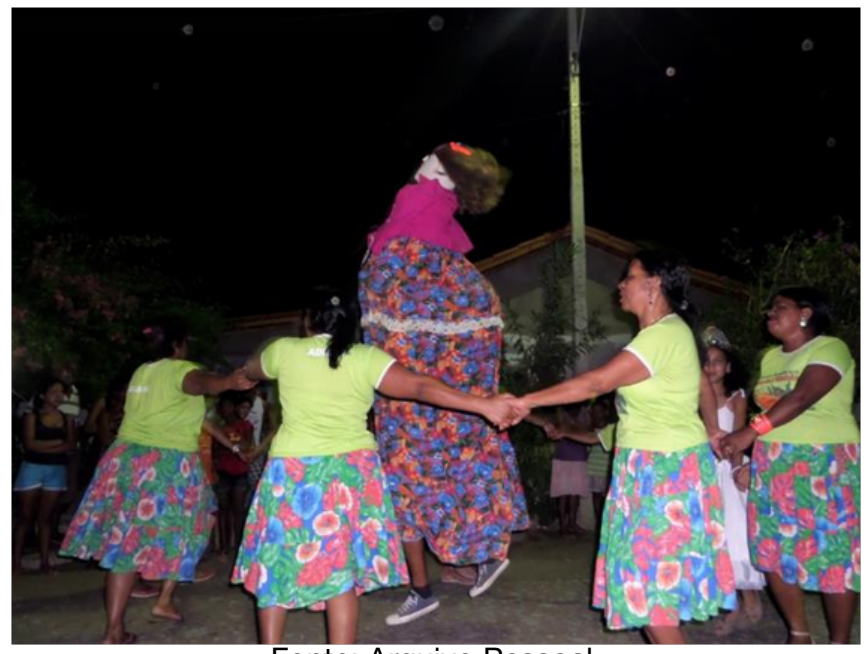

Fonte: Arquivo Pessoal

Figura 10: Boi-Janeiro em cortejo pelas ruas da cidade. Rubim, 2016. Foto: Mariana Floriano

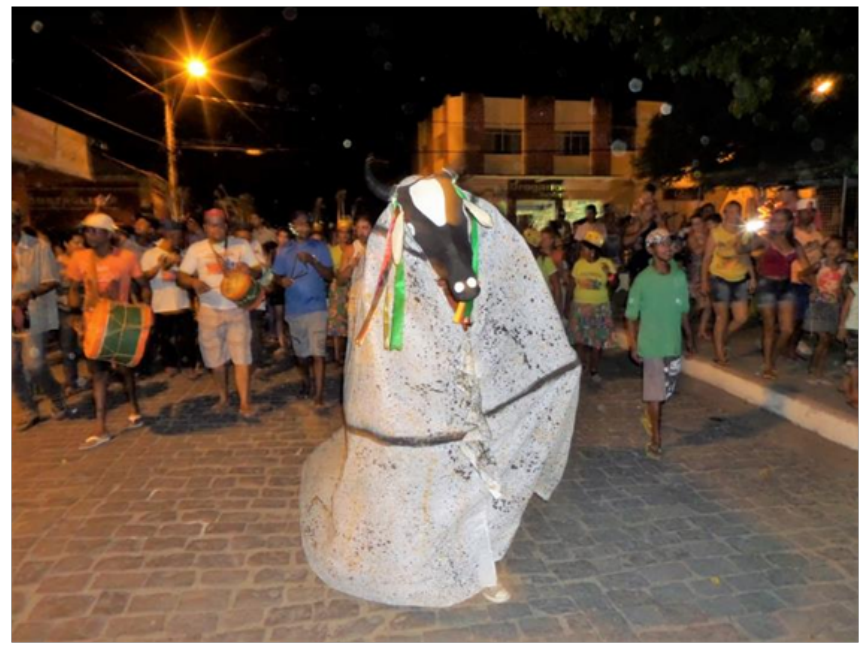

Fonte: Arquivo Pessoal.

\section{- Recebeis aos Santos Reis com seus nobres foliões ...}

Consagrando a época festiva, os brincantes de boi uniam-se nas madrugadas quentes de Rubim, para cantar aos Santos Reis. A folia de Reis e o Boi-Janeiro encontravam-se intimamente conectados, pois ambas estavam inseridas em um ciclo, no qual os reiseiros apresentavam-se como foliões e brincantes. A vestimenta, que os batuqueiros e as pastorinhas usavam na brincadeira do boi, virava a farda para os foliões cantarem madrugada adentro.

A Folia de Reis dos Coquis iniciou na virada do dia 31 de dezembro para o dia 1 de janeiro, com a ida dos foliões ao cemitério. O primeiro "reis" foi cantado para os antepassados da festividade. Em meio aos montes secos de terra, com cruzes de madeira, os foliões ascendiam velas, tocavam os instrumentos e reverenciavam os foliões que já partiram.

A dinâmica instaurada, após a Folia de Reis visitar o cemitério, consistia em caminhar pelas ruas da cidade, carregando uma bandeira com a pintura dos Santos Reis, onde o grupo "batia com cantoria" na porta dos devotos. As casas visitadas pelos foliões eram de devotos aos santos, pessoas que pediam a benção e que cumpriam promessa, recebendo os reiseiros. Entretanto, a Folia de Reis não saia todas as noites; a quantidade de devotos, de pedidos de visita e de abertura das portas vem diminuindo a cada ano. Caso o dono da casa abrisse a porta, o grupo entrava na casa e lá, na frente do presépio, "cantava mais um reis". Quando o dono não abria, os foliões seguiam percorrendo a cidade noite afora.

O grupo de "reis" tinha, em seu "repertório", canções intituladas como sendo de homem e outras de mulher. A musicalidade era composta por qualidades que pertenciam a cada um dos gêneros. A melodia e a marcação das folias eram ditadas pela sanfona, pela viola, pelo triângulo, pelo pandeiro, pela caixa e pelo bumbo. A "folia de mulher" possuía uma sonoridade embalada e aguda, instaurava uma atmosfera chorosa e piedosa ao canto. A "folia de homem" continha uma característica pontuada e grave, apresentava um enfeite sonoro 
ditado pelas gaitas ${ }^{10}$.

Em certas casas, os devotos pediam a contradança. Os seis homens foliões ajeitavam-se em uma roda na sala e iniciavam uma cantoria abraçada com os instrumentos. A contradança consistia em uma animada e firme dinâmica manifestada nos corpos e nas vozes dos homens que permaneciam ziguezagueando entre si. A contradança despertava a noite, ascendia a vibração do ambiente e regava o corpo dos foliões com energia.

No dia 6 de Janeiro de 2016, o grupo Coqui encerrou a cantoria de "reis" com a reza do terço. Depois da brincadeira do Boi Janeiro cortejar pela cidade, os brincantes chegaram na porta azul da casa de Dona Maria e, lá, os reiseiros preencheram os espaços vazios da sala. Os foliões iniciaram uma folia e a anfitriã ajoelhou-se em meio às velas que rodeavam seu presépio de areia. Ela segurava uma vela na mão direita, abraçando-a com os dedos. A canção embalava o ambiente. Maria Coqui chorava.

Ao longo da cantoria, Dona Maria entrou em outro estado corporal. De olhos fechados, a sua mão impunha mais força sobre a vela e tremia. A postura vertical da coluna passou para a abaulada, conforme a intensidade do tremor aumentava. Seu corpo mostrava um estado diferente do que até então havia apresentado, similar ao transe. No fim da canção, ela fincou a vela no chão, acomodando-se no chão apoiada sobre as pernas e os pés.

O corpo em transe ${ }^{11}$ de Maria Coqui mani-

10 Espécie de flauta. De acordo com o Dicionário do Folclore Brasileiro, gaita é uma "flauta, de taboca, bambu ou flandres, reta, espécie de pífaro" (CASCUDO, 2012, p. 320).

11 Refere-se aqui ao transe presenciado por exemplo nos terreiros de Umbanda em que há a incorporação de entidades promovendo uma mudança tônica, de voz e de postura como se fosse um outro atuando. Segundo Rodrigues e Turtelli(2017, p.144), "o corpo do médium centraliza o processo, festava-se com palmas e com uma pulsação do tronco. As mulheres choravam enquanto cantavam. No final da canção, a música foi ofertada à Silvano - filho de Dona Maria, falecido há seis anos. Ainda sentada sobre as pernas, "ela"12 acomodou a região do peito sobre os joelhos, permanecendo em posição fetal. Nesse momento, "ela" começou a gemer num tom baixo. A intensidade do gemido foi aumentando, conforme sua postura retomava a verticalidade. Seu corpo em transe fazia uma ação como se procurasse algo com as mãos. Seus filhos ajudaram-na a se levantar do chão.

De olhos fechados, as suas mãos intercalavam entre a ação de procurar e a de chamar pelos outros. Era perceptível que "ela" atuava em outro estado de sintonia pois "ela" chegava até os foliões e os devotos, sem que seus olhos abrissem. O encontro do corpo em transe de Maria Coqui com aqueles que a cercavam, revelou uma ação singular para com cada um. "Ela" distribuía abraços, batidas no peito, beijos e benzimentos. Os foliões também reagiam de forma individualizada, choravam de modos e intensidades diferentes.

"Maria" continuava a procurar os corpos pela sala, quando encostou na pesquisadora, primeira autora desse artigo. "Maria" abraçou-a e disse: "ô meu Deus, me ajude! Me ajude, meu Deus!". Seu pedido era em tom piedoso. "Ela" dirigiu-se à todos os foliões, pedindo para eles não deixarem essa folia terminar, para eles continuarem fortes. "Ela" encontrou-se com

como se ele recebesse substancias de um outro corpo, diferente do seu. As incorporações são precedidas de sensações físicas especificas, vibrações no corpo (...)".

12 Optamos pela utilização das aspas para diferenciar Maria Coqui em estado de transe. O que manifestava em seu corpo, durante o transe, era desconhecido por todos os integrantes da sua família. Em uma conversa com Dona Maria, foi possível desvelar que ela sabia quem se manifestava em si durante o transe, mas ela preferia não contar a ninguém. 
os últimos foliões e devotos e, no fim, "ela" chamou novamente pela pesquisadora. "Ela" abraçou forte, começou a apalpar os braços e seios, chegando até a barriga e, depois, bateu forte sobre o estômago. Era perceptível a força de "Maria". "Ela" se afasta e, nesse momento, foi acolhida pela sua sobrinha. O seu corpo inclinou para a postura horizontal da coluna, com uma das mãos nos joelhos e a outra na sua sobrinha. Maria Coqui recobrou a verticalidade já com os olhos abertos, levou as mãos sobre a cabeça, caminhou até um dos cantos da sala e, lá, sentou em um tamborete. Chegava ao fim o estado de transe.

Neste mesmo instante, uma das mulheres iniciou o terço, sentada à frente do presépio que guardava o Menino Jesus, apresentando uma dinâmica ritmada da voz na reza. Após o "Salve Maria", uma das filhas da dona da casa finalizou a oração com uma canção. A bandeira foi retirada do presépio e, um a um, os participantes do terço ajoelharam-se na frente da bandeira e a beijaram, findando com a saudação de Maria Coqui: "Viva Santos Reis! Viva o menino Jesus! Viva os foliões!" foram as últimas palavras antes dos devotos espaIharem-se pela casa.

Figura 11: Folia de Reis no cemitério. Rubim, 2016. Foto: Mariana Floriano

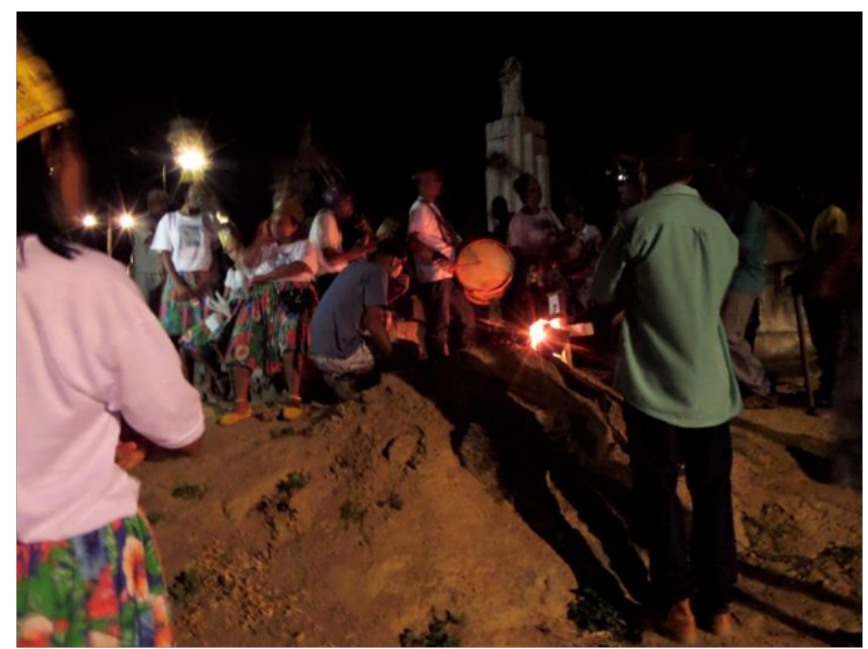

Fonte: Arquivo Pessoal.
Figura 12: Mulheres cantando folia na casa de devoto. Rubim, 2016. Foto: Mariana Floriano.

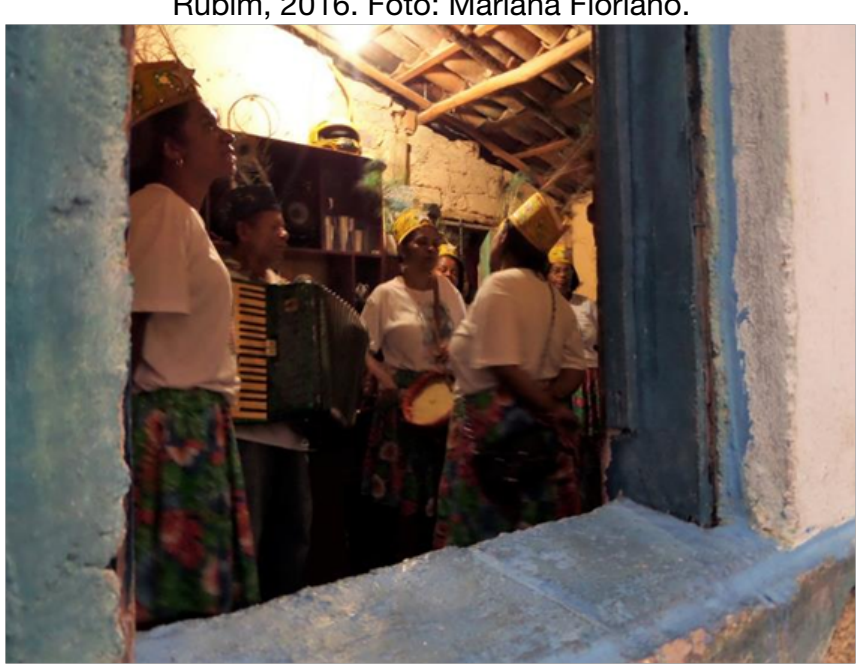

Fonte: Arquivo Pessoal.

Figura 13: Dona Maria, em transe, benzendo a pesquisadora. Rubim, 2016. Foto: Jaqueline Soraia.

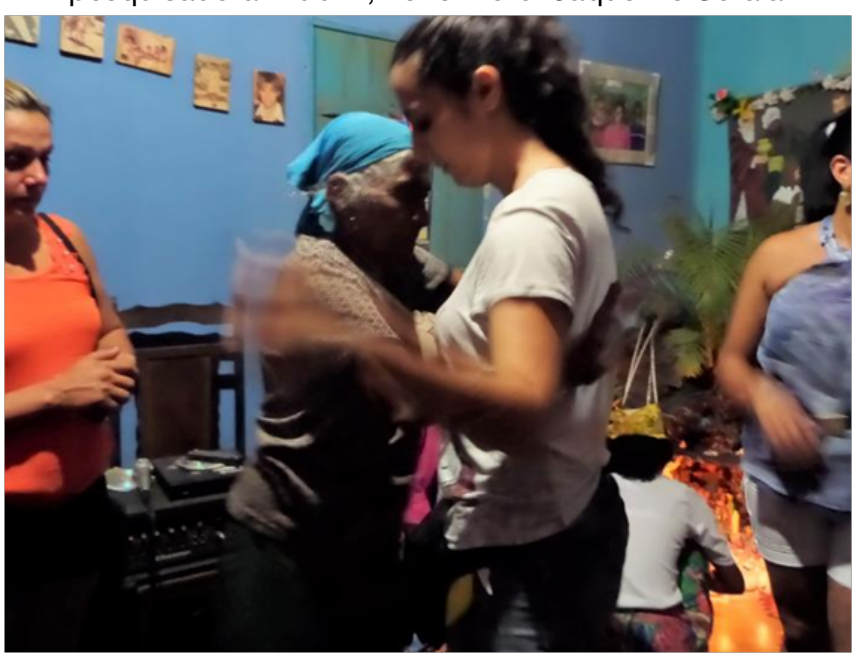

Fonte: Arquivo Pessoal.

Figura 14: Dona Maria ajoelhada na frente do presépio. Rubim, 2016. Foto: Mariana Floriano.

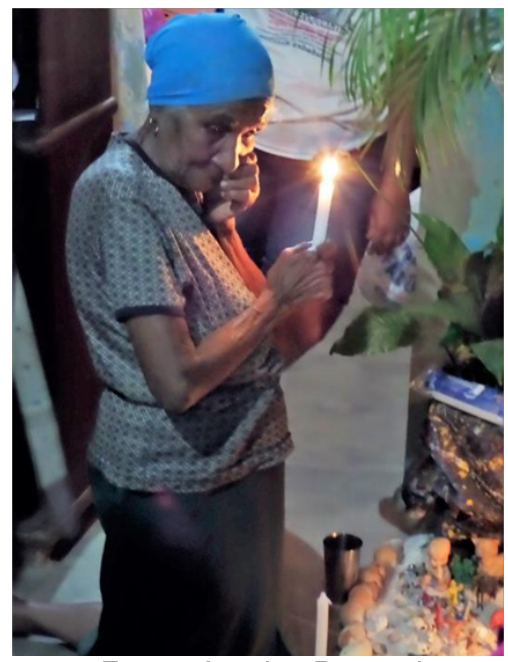

Fonte: Arquivo Pessoal.

Floriano, Rodrigues // Corpos de Afeto: 
Figura 15: Dona Maria Coqui e o seu presépio de areia. Rubim, 2016. Foto: Mariana Floriano.

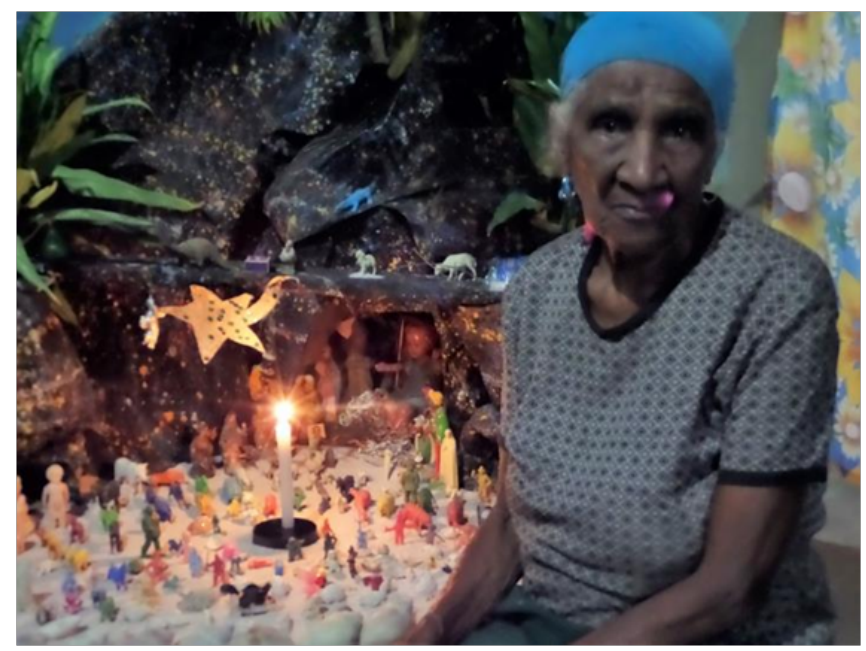

Fonte: Arquivo Pessoal.

\section{A afetividade em campo}

Maria Coqui, atualmente com 85 anos, mantém-se forte na condução das festividades. Ao ver os vídeos da pesquisa, realizada anteriormente, em 1988, ela mostrou-se emocionada pelo retorno da pesquisa à sua casa. Enquanto assistia, ela gesticulava, trazendo um movimento de fincar com as mãos, como se sovasse a terra e contava: "essa folia de boi tá enraizada nessas terra, criando raízes que vão além de mim".

A herança da promessa, que funda a festividade, é passada de geração para geração. No caso da Folia de Reis e do Boi de Janeiro, Dona Maria herdou de sua mãe que fez a promessa aos três reis santos para se curar de uma grave doença. A Folia para São Sebastião, festejada de 9 a 20 de Janeiro, foi uma promessa que Dona Maria fez para seu filho Adimilson, quando ele ainda era uma criança, e mesmo com a morte do filho, a folia segue saindo pelas ruas. É assim também com a festa para Bom Jesus, realizada no mês de agosto, prometida pelo seu marido já falecido.

A festividade ocupa o círculo familiar e como diz Maria Coqui, vai além de uma pessoa, indo além até da morte. $\mathrm{O}$ seu neto que nos registros de 1988 era um bebe em seu colo (vide figura 2), hoje, está no comando da brincadeira de Boi. O filho que antes seguia a contradança ao lado do pai, atualmente é o condutor do violão à frente dos homens. As jovens pastorinhas de antes, agora, são mulheres que, junto com Dona Maria, relatam as perdas de seus familiares e cantam seus hinos chorosos para os santos. Foram filhos/irmãos, netos, bisnetos e marido/pai que partiram ao longo desses trinta anos, deixando marcas profundas nas muIheres dessa família. Mesmo com a morte de seu filho e de seu marido, fato ocorrido anos depois das promessas firmadas, Dona Maria e sua família mantiveram as festividades como ciclos sagrados de celebração; tempo de renovação da fé e de devoção aos santos que os aparam nos momentos de dificuldade.

A obrigação com os mortos torna-se fortemente presente nessa pesquisa de campo, através da manutenção das promessas, das cantorias de folias no cemitério, nos túmulos dos ancestrais. Há uma força recolhida nessa reverência aos antepassados. Além disso, no âmbito familiar dos Coquis, foram encontrados laços de comunicação dos vivos com as almas. Os mortos manifestaram-se através de incorporações e de "aparições" em sonhos. Dona Maria conta que com a morte de sua filha Nadilva, a brincadeira do boi ficou sem uma herdeira, e que anos depois, ela sonhou com a filha falecida entregando-lhe um bebê. Naquela mesma época, sua filha caçula estava grávida. Dona Maria entendeu o recado da alma de sua filha, como sendo, a entrega de sua nova herdeira. E, desde então, Maria Coqui afirma: "eu já sei quem será minha herdeira. Será minha neta". 
"A própria pessoa realiza a interpretação dos seus sonhos, relaciona a "aparição" dos mortos como uma necessidade de comunicar-se, seja para pedir ajuda ou para ajudar. Essa leitura religiosa que fazem sobre os sonhos gera uma relação de interação com as almas. (...) Existe então uma relação de reciprocidade entre os habitantes do mundo terreno e do transcendente (...)". (TAVARES, 2014, p. 55 e 56).

Esse relato evidencia a atuação dos mortos como agentes de resistência e de preservação da festividade. De acordo com Tavares (2014, p.52), "enaltecer a presença contínua dos laços de sociabilidade e afirmar que nesse grupo os laços permanecem mesmo após a morte, [é dizer que] eles não se rompem, na verdade, fortalecem-se". Nesse âmbito familiar fortalecido, como o da família Coquis, era expressivo o campo afetivo que vibrava dos corpos pesquisados, tanto na relação interpessoal, seja com os vivos ou mortos, como na relação com os objetos e símbolos que caracterizavam a festividade. A afetividade, a que nos referimos, acolhe os sentimentos e as emoções e "são as marcas afetivas que dão vitalidade, sentido e colorido às nossas ações e aos nossos vínculos" (NERY, 2014, p. 19).

Os espaços ocupados pelo Boi e sua folia, seja a sala, o terreiro de Maria Coqui, o cemitério, as ruas de paralelepípedos, a praça da cidade ou os tantos outros espaços percorridos no entremeio desse folguedo, vibravam com os sentidos atribuídos à manifestação.

No grande terreiro ocupado pelo Boi-Janeiro de Maria Coqui, havia uma conexão afetiva que alicerçava o sentimento de pertencimento às terras em que a herança teima em vingar. Foi perceptível, para ambas as autoras, a capacidade desse núcleo em resistir culturalmente, a captação de um vínculo emocional gestado nas relações com os familiares vivos, com os que já se foram e com os que estão por vir. Em seu livro, a segunda autora, ao trazer um recorte sobre a pesquisa do Boi de Janeiro, realizada em 1988, evidencia: "naqueles corpos um pulso se mantinha, junto a uma força surpreendente: eram corpos ainda ligados a uma herança que lhes aguçava os sentidos" (RODRIGUES, 1997, p. 67).

Dona Maria, até os últimos minutos ao seu lado, demonstrou a sua resistência em seguir em frente, consciente que ela também partirá um dia. Porém, ela não deixará sua crença, sua devoção e principalmente sua folia para trás. Nos sonhos, ela diz que visitará seus herdeiros, que lhes contará histórias de uma folia que teima em fincar raízes em terras secas. "Deus já levou, já, as pessoas que não
mora mais aqui comigo. Mas aqueles
que ficá, vai passá um pelo outro, um
pelo outro. É de geração pra geração.
E é isto aí. Era uma florzinha. Morre
uma nasce outra. Mas a raiz não mor-
re. Tá enterrada. E há de vim um neto,
um bisneto, os mais novos que for
chegando. Talvez não tem, vai chegá.
Vem vindo. Pelo menos no sonho, vố
contá história pra eles que vié chegá.
É meu povo! Seja o que Deus quisé,
Menino Jesus aceita". (Relato de Maria
Coqui, registrado em 11 de janeiro de
2016).

\section{O processo criativo desvela a} resistência coabitada

A pesquisa de campo, realizada no Boi-Janeiro de Maria Coqui, foi parte integrante do desenvolvimento do processo de criação do espetáculo Vale da Esperança, tendo como intérprete a primeira autora e direção da segunda autora desse artigo. A metodologia utilizada no processo foi o Bailarino-Pesquisador-Intér- 
prete (BPI), criado na década de 80 e desenvolvido ao longo de mais de 30 anos no Departamento de Artes Corporais e no Programa de Pós-Graduação em Artes da Cena, ambos da UNICAMP.

O Método Bailarino-Pesquisador-Intérprete (BPI) consiste em uma metodologia de pesquisa e criação em Dança que permite ao intérprete "dançar de posse da própria identidade" (RODRIGUES, 2003, p. 159), pois lida com o corpo real (RODRIGUES, 2003) ao valorizar o que esse corpo irá produzir empossado com sua história em contínuo desenvolvimento e dinamismo. O processo prioriza o percurso interno e está intimamente ligado às imagens deste corpo na sua relação de existência em si e no mundo. O BPI é sistematizado em eixos ${ }^{13}$ e ferramentas ${ }^{14}$ que auxiliam o bailarino-pesquisador-intérprete "na busca por um corpo vigoroso e mobilizado internamente" (RODRIGUES e outros, 2016, p. 552), em um trabalho conduzido por uma meticulosa direção, específica neste Método.

A pesquisa de campo no Método BPI tem como foco o encontro com corpos em que a potência interna reverbera em movimentos com uma rica qualidade expressiva (RODRIGUES, 1997). Essa é a fase em que se busca vivenciar uma experiência que toca no âmbito das relações humanas, em que o eixo é O Co-habitar com a Fonte.

130 Método BPI estrutura-se em três eixos que atuam de forma sistêmica, podendo, também, ser consideradas fases do processo: O Inventário no Corpo, O Co-habitar com a Fonte e A Estruturação da Personagem. Seus eixos permeiam todo o processo em contínuo movimento. Para saber mais veja Rodrigues (2003).

14 Cinco ferramentas dão suporte ao percurso no Método BPI, são elas: A Técnica de Dança, a Técnica dos Sentidos, a Pesquisa de Campo, os Laboratórios Dirigidos e o Registro. Para saber mais veja Rodrigues (2010a).

\begin{abstract}
"Para adentrar no eixo Co-habitar com a Fonte o Intérprete escolhe um segmento social/cultural para realizar uma pesquisa de campo. A afetividade faz parte dessa escolha, até é imprescindível, pois galgar uma sintonia fina com o outro será a principal tarefa deste momento. (...) O Intérprete, ao mesmo tempo em que capta o corpo do outro, está atento ao seu próprio corpo, às suas emoções e às emoções do outro. (...) O corpo capta a essência da experiência de campo e dele próprio, que irá reverberar no trabalho que se segue". (RODRIGUES, 2010b, p. 2).
\end{abstract}

Nos anos de 2015 e 2016, a primeira autora trafegou por paisagens brasileiras permeadas pela figura do boi, seja ela ligada à lida do gado ou aos festejos. Foram realizadas pesquisas de campo nos festejos do Bumba-meu-boi do Maranhão, Boi-Janeiro de Minas Gerais e com os Boiadeiros do Mato Grosso do Sul. A intérprete esteve no Vale do Jequitinhonha (MG), em São Luiz (MA), em Pindaré Mirim (MA) e na Fazenda Margarida (MS).

O amplo caminhar possibilitou encontrar, nos campos pesquisados, distintos contextos sociais e econômicos, e adentrar em outras realidades, deparando, muitas vezes, com uma dramaturgia de vida conectada à celebração e à fé. $O$ ato de celebrar - com seus elementos de festividade e de fantasia (COX, 1974) - evidenciou afetos associados aos modos de viver dessas pessoas. O fazer e o celebrar caminhavam juntos, embrenhados nas paisagens próprias de cada lugar pesquisado.

Foi nesse percurso, atrás dos bois do Brasil, que o Boi-Janeiro de Maria Coqui foi revisitado pela jovem pesquisadora. Nesse encontro foi vivenciado um campo festivo e afetivo dotado de uma riqueza imensurável, no qual não tinha como parâmetro a observação dos bens materiais que a festividade continha em si, mas 
sim, a potência interna que a manifestação gerava nos corpos das pessoas pesquisadas. $A$ vivência de coabitar estava rodeada de pessoas conectadas por laços de afeto que geravam corpos carregados de uma potência que se remetia à uma gana, à uma força, à um impulso de celebração, vinculado a vida dessas pessoas, sendo que, muitas vezes, era percebida uma conexão direta com o modo como elas enfrentavam as faltas e as adversidades e como elas resistiram frente à essas situações. A resistência era visível no corpo delas. Havia esperança.

"Não vamos falar da "esperança" no sentido usual do termo, ou seja, da esperança como mera expectativa. Considero a esperança uma virtude, não daquelas teologais, mas como força intrínseca. Em outras palavras, aquilo que a filosofia definiria como uma força intrínseca para a realização de um objetivo. (...) a esperança é tomada como uma força vital, uma força de animação. Ela é uma qualidade sagrada, nesse sentido de divina mesmo, ou seja, como impulso vital do humano. Tenha o caráter que for, seja o de pulsão freudiana, seja o da própria noção de anima, a esperança é algo que nos leva a procurar um momento de paz, do estar bem, da suspensão da amargura e da carência, a possibilidade de sempre desejar um estado que tende ao perfeito, no sentido latino de feito por completo (a ideia de completude, de plenitude, essa busca do pleno)". (BETTO, 2012, p. 7 e p. 13).

A esperança revela uma outra perspectiva, com mais vida. Ela é combustível. Ela gera movimento. No Boi-Janeiro de Maria Coqui, o fluxo de movimento percorria os diversos níveis e direções, cruzando o caminho de devotos aos santos, seguindo em frente em busca de meninos brincalhões. As raízes ficando nas terras, imaginário que Dona Maria traz ao falar do festejo, é a imagem pontual para demonstrar a profundidade dessa celebração para essas pessoas. Uma profundidade que se relaciona à memória e à esperança, à um pertencimento individual e coletivo.

No trabalho cênico "Vale da Esperança" é perceptível os conteúdos relacionados à festividade do Boi-Janeiro e ao amplo contexto no qual ele estava alocado. Os conteúdos, que integram o roteiro desse espetáculo, trafegam por paisagens de seca e de mata, trazendo uma mulher que tem a lembrança, em seu corpo, de um filho perdido. Essa mulher possui diversas facetas corporais modeladas em si: a boiadeira, a mulher da seca, a bandeireira, a cabocla, a moça e a curandeira. Todas elas se integram no corpo da intérprete a personagem "Moça da Mata".

No processo criativo não poderia deixar de existir a sala de Maria Coqui. A construção cênica deste espaço traz o imaginário da sala cheia de foliões que rezam e cantam na frente do presépio. De lá, abre-se as paisagens de seca do cemitério, onde a folia visita os que ali são enterrados. O corpo que chora as perdas e que reverbera em fé, em dança, em promessa e que se revitaliza através da esperança.

A resultante cênica revela o quão forte a pesquisa de campo junto à Maria Coqui nutriu esse processo criativo. No roteiro do espetáculo, quando a porta imaginária da sala da casa de Coqui é aberta, os meninos são desenterrados. A sala minúscula encontrada em campo era um espaço de vivência e convivência carregado de afeto. Dela saíram os foliões, os brincantes, as mulheres chorosas, os meninos e o Boi que possibilitaram a força motriz para a criação artística. O folguedo e a folia de Coqui fundamentaram um roteiro que emana o impulso em busca de vida.

No Processo BPI, a concepção do roteiro 
preza pelos conteúdos que emergem do corpo do interprete sintonizado com as pesquisas de campo realizadas por ele. Há um roteiro de sensações que emolduram um conteúdo expressos através do movimento. Para esta travessia, a pesquisa de campo no Método BPI é uma ferramenta que oportuniza ao intérprete uma gama de relações. É o momento de ir para fora, para em seguida possibilitar um retorno para dentro de si. É o momento de entrar em contato com uma dramaturgia viva (RODRIGUES, 2010a).

A experiência no Vale do Jequitinhonha de ambas as autoras - diretora e intérprete - as colocou diante de pessoas que possuem uma incomensurável força de superação e essa coabitação levou a um processo corporal no qual a esperança é a tônica numa dramaturgia de vida e morte. A prevalência de conteúdos conectados ao simbolismo e ao contexto social do Boi-Janeiro, no eixo dramatúrgico da obra, se deu pelo manancial expressivo e emocional coabitado em pesquisa de campo. Efetivamente o Boi de Maria Coqui, atravessado pelo tempo, levou para o processo criativo do Vale da Esperança, uma amplitude de corpo e de vida que é preciso reverberar.

Figura 16: Cena do espetáculo em que a Boiadeira conduz o gado. Mostra Unidança, Campinas, 2016. Foto: João Maria.

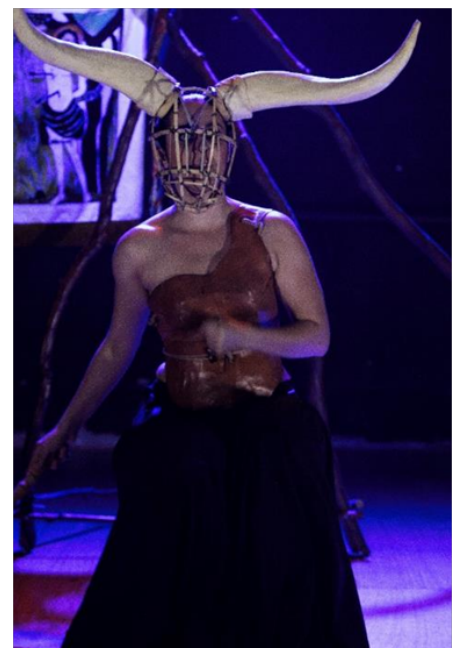

Fonte: Arquivo Pessoal.
Figura 17: Cena do espetáculo em que a mulher arranha as terras secas do cemitério. Mostra Unicamp 50 anos, 2016. Foto: Alessandra Guedes.

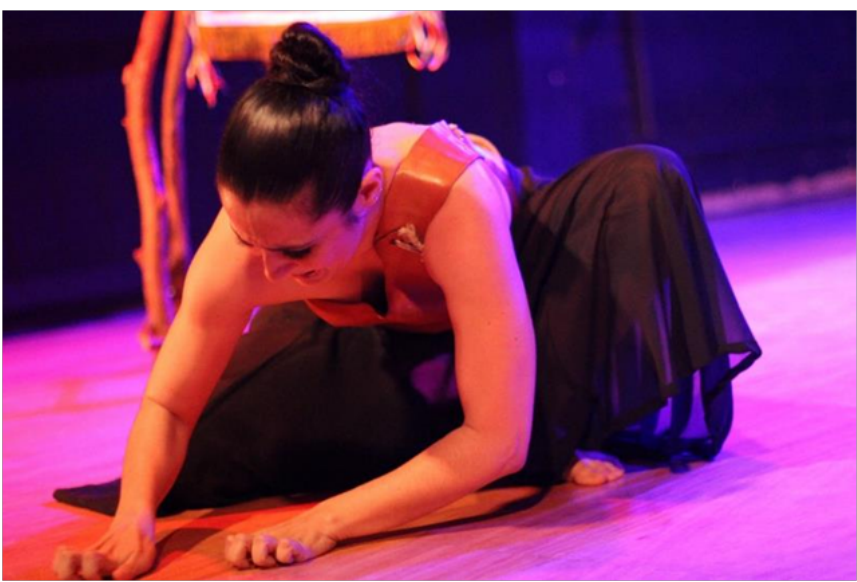

Fonte: Arquivo Pessoal.

Figura 18: Cena do espetáculo em que a Bandeireira trafega as terras secas. Mostra Unidança, 2016. Foto: Nara Cálipo.

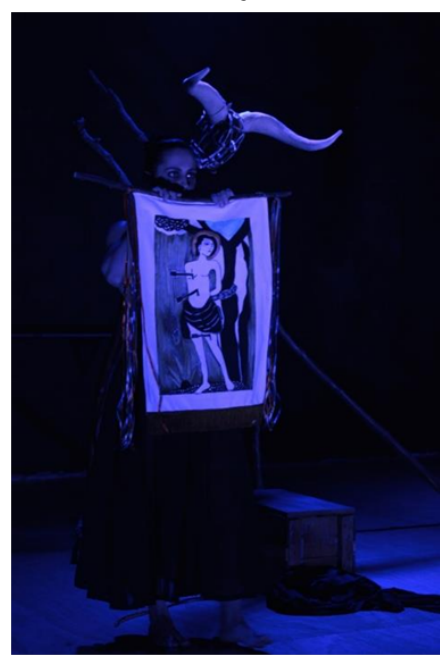

Fonte: Arquivo Pessoal.

Figura 19: Cena do espetáculo em que a Moça atua como miolo do boi. Mostra Unicamp 50 anos, Campinas, 2016. Foto: Alessandra Guedes.

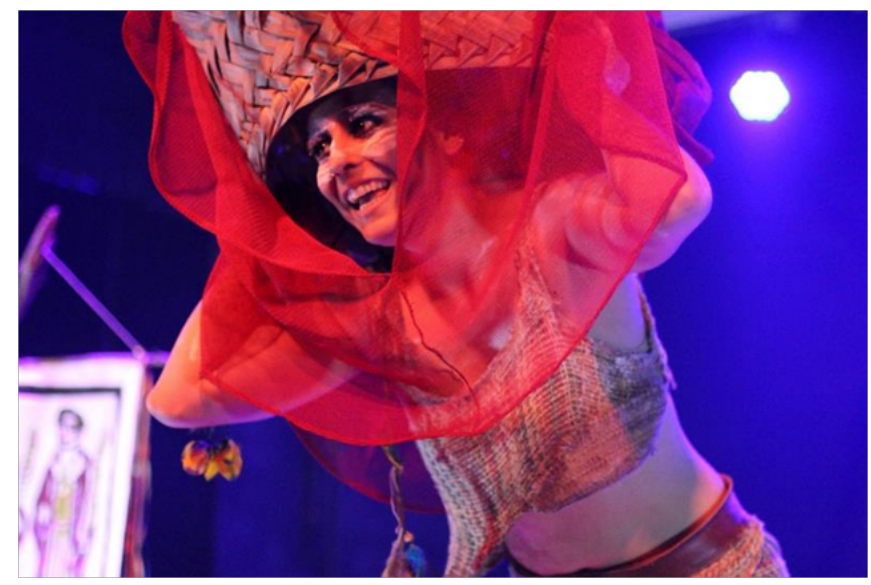

Fonte: Arquivo Pessoal. 


\section{Referências}

BETTO, F. Sobre a esperança: diálogo (Frei Betto e Mario Sergio Cortella). Campinas: Papirus 7 Mares, 2012, $5^{\text {a }}$ ed. Coleção Papirus Debate.

BORBA, H. Espetáculos populares do Nordeste. São Paulo: Buriti, 1966.

BRITO e outros. A festa do boi de Pedra Azul: aspectos históricos, estruturais e socioculturais. In: Revista Intercâmbio, v. VII, 2016.

CARVALHO, D. C. Aqui meu boi vai urrar: uma leitura espacial do bumba-meu-boi na cidade de São Luís (MA). Dissertação (Mestrado em Geografia) - Universidade Federal Fluminense, Niterói, 2009.

CASCUDO, L. C. Dicionário do folclore brasileiro. $12{ }^{\text {a }}$ ed. São Paulo: Global, 2012.

COX, H. A festa dos foliões: um ensaio teológico sobre festividade e fantasia. Tradução de Edmundo Binder. Petrópolis, RJ: Editora Vozes. 1974.

FERREIRA, A. B. H. Novo Aurélio Século XXI: o dicionário da língua portuguesa. Rio de Janeiro: Nova Fronteira, 1999, $3^{\text {a }}$ ed.

IBGE. Diagnóstico Ambiental da Bacia do Rio Jequitinhonha: diretrizes gerais para a ordenação territorial (supervisor Ronaldo do Nascimento Gonçalves). IBGE: Salvador, 1997.

Divisão regional do Brasil em mesorregiões e microrregiões geográficas. DEGEO: Rio de Janeiro, 1990.
IPHAN/MA. Complexo Cultural do Bumba-meu-Boi. Dossiê do Registro como Patrimônio Cultural do Brasil. São Luís: Iphan/MA, 2011.

NASCIMENTO, E. C. Vale do Jequitinhonha: entre a carência social e a riqueza cultural. In: Contemporâneos Revista de Artes e Humanidades, n.4, 2009.

NERY, M. P. Vínculo e Afetividade: caminho das relações humanas. São Paulo: Editora Ágora, 2014.

RODRIGUES, G. Bailarino-Pesquisador-Intérprete: processo de formação. Rio de Janeiro: Funarte, 1997.

O Método BPI (Bailarino-Pesquisador-Intérprete) e o desenvolvimento da imagem corporal: reflexões que consideram o discurso de bailarinas que vivenciaram um processo criativo baseado neste método. 2003. 171p. Tese (Doutorado em Artes) - Instituto de Artes, Universidade Estadual de Campinas, Campinas, 2003.

As Ferramentas do BPI (Bailarino-Pesquisador-Intérprete). In: Anais do I Simpósio Internacional e I Congresso Brasileiro de Imagem Corporal (ISBN: 9788599688120). UNICAMP. Campinas, SP. 2010a.

O que é BPI (Bailarino-Pesquisador-Intérprete)? O caminho do Intérprete. In: Anais do I Simpósio Internacional e I Congresso Brasileiro de Imagem Corporal (ISBN: 9788599688120). UNICAMP. Campinas, SP. 2010b. 
RODRIGUES e outros. Corpos em expansão: a arte do encontro no método Bailarino-Pesquisador-Intérprete (BPI). In: Revista Brasileira de Estudos da Presença, Porto Alegre, v. 6, n. 3, p. 551-577, set./dez. 2016.

RODRIGUES, G. E. F.; TURTELLI, L. S. Umbanda e método Bailarino-Pesquisador-Intérprete (BPI): confluências. In: Urdimento, v.1 n.28, p.139-158, julho 2017.

SERVILHA, M. M. Vale do Jequitinhonha: a emergência de uma região. In: Vale do Jequitinhonha: Cultura e desenvolvimento. Organização: Maria das Dores Pimentel Nogueira. Belo Horizonte: UFMG/PROEX, 2012.

TAVARES, T. R. Rituais funerários no Vale do Jequitinhonha: a vivência popular do catolicismo e as transformações nas atitudes dos homens frente a morte. 2014. 117p. Dissertação (Mestrado em Ciência da Religião) - Instituto de Ciências Humanas, Universidade Federal de Juiz de Fora, 2014.

Recebido: 16/03/2016

Apovado: 26/02/2018 